\title{
REVIEW: ANALISIS KONSENTRASI ION SULFAT DALAM AIR MENGGUNAKAN SPEKTROFOTOMETRI
}

\section{REVIEW: ANALYSIS OF SULPHATE ION CONCENTRATION IN WATER USING SPECTROPHOTOMETRY}

\author{
Zelika Nur Jannah, Dheasy Herawati dan Khoirul Ngibad* \\ Program Studi Teknologi Laboratorium Medik Fakultas Ilmu Kesehatan Universitas Maarif Hasyim Latif, Sidoarjo, \\ Indonesia \\ *Email: khoirul_ngibad@dosen.umaha.ac.id
}

Diterima: 31 Mei 2020. Disetujui: 12 Februari 2021. Dipublikasikan: 3 Maret 2021

\begin{abstract}
Abstrak: Review ini bertujuan untuk mengkaji metode spektrofotometri dalam pengukuran kadar sulfat dan mengkaji aplikasi metode spektrofotometri untuk pengukuran kadar sulfat yang terdapat dalam beberapa jenis sampel air. Penentuan kadar sulfat dalam air menggunakan metode spektrofotometri dapat dilakukan menggunakan reagen $\mathrm{BaCl}_{2}$ kemudian absorbansinya diukur pada panjang gelombang $420 \mathrm{~nm}$. Metode spektrofotometri dapat diaplikasikan untuk penentuan konsentrasi ion sulfat dalam air sumur bor, air minum dalam kemasan, air minum isi ulang, dan air hujan. Hasil menunjukkan bahwa kadar sulfat dalam sampel air berada di bawah ambang batas. Kadar maksimum kandungan sulfat dalam air minum menurut Permenkes No. 492/MENKES/PER/IV/2010 adalah $250 \mathrm{mg} / \mathrm{L}$ dan kadar maksimum kandungan sulfat dalam air untuk keperluan higiene sanitasi menurut Permenkes No. 32 Tahun 2017 adalah 400 $\mathrm{mg} / \mathrm{L}$.
\end{abstract}

Kata Kunci: Spektrofotometri, Sulfat, Air

\begin{abstract}
This review aims to examine the spectrophotometric method for measuring sulfate levels and examine the application of the spectrophotometric method for measuring sulfate levels contained in several types of water samples. Determination of sulfate levels in water using the spectrophotometric method can carried out using the $\mathrm{BaCl}_{2}$ reagent then the absorbance was measured at wavelength of $420 \mathrm{~nm}$. The spectrophotometric methods can be applied to determine the concentration of sulfate ions in wellbore water, bottled drinking water, refill drinking water, and rainwater. The results showed that sulfate levels in water samples were below the threshold. The maximum level of sulfate content in drinking water according to Permenkes No. 492 / MENKES / PER / IV / 2010 was 250 mg / L and the maximum content of sulfate in water for sanitary hygiene requirements according to Permenkes No. 32 Year of 2017 was $400 \mathrm{mg} / \mathrm{L}$.
\end{abstract}

Keywords: Spectrophotometry, Sulfate, Water

\section{PENDAHULUAN}

Air adalah senyawa yang sangat penting di dalam kehidupan sehari-hari karena air digunakan untuk berbagai macam kebutuhan, misalnya: untuk mengairi persawahan, memasak, mencuci, mandi, dan air minum. Jenis - jenis air sendiri bisa meliputi: air bersih, air minum, air pemandian umum dan air kolam renang [1]. Di Indonesia sudah banyak perairan yang tercemar akibat limbah pabrik dan rumah tangga yang berupa sabun atau detergen. Dengan demikian, kualitas air harus dipertahankan agar air dapat dimanfaatkan sebagaimana mestinya.

Kualitas air dapat dilihat dari 3 aspek, yaitu: aspek fisik, kimia dan mikrobiologi. Aspek fisik meliputi: warna, kekeruhan, bau, rasa, suhu, dan total zat padat terlarut (TDS). Aspek kimia meliputi, $\mathrm{pH}$, besi, fluorida, kesadahan $\left(\mathrm{CaCO}_{3}\right)$, mangan, nitrat, nitrit, sianida, deterjen, pestisida total, air raksa, arsen, kadmium, kromium, selenium, seng, sulfat, timbal, benzena dan zat organik $\left(\mathrm{KMNO}_{4}\right)$ sedangkan aspek mikrobiologi meliputi: E.coli dan total bakteri koliform [2].

Salah satu aspek kimia dalam penentuan kualitas air adalah kadar ion sulfat $\left(\mathrm{SO}_{4}{ }^{2-}\right)$. Menurut Permenkes No. 492/MENKES/PER/IV/2010, kadar maksimum sulfat dalam air minum adalah $250 \mathrm{mg} / \mathrm{L}$. Akan tetapi berdasarkan Permenkes No. 32 tahun 2017 kadar maksimum sulfat yang digunakan air untuk keperluan higiene sanitasi yaitu $400 \mathrm{mg} / \mathrm{L}$. Bahaya ion sulfat apabila dikonsumsi dengan kandungan sulfat yang cukup besar dapat menyebabkan laxative / diare [3].

Metode spektrofotometeri UV-Vis telah banyak digunakan untuk analisis kadar sulfat [3], [4], ammonium [5], dan fosfat [6]. Konsentrasi analit dalam sampel dapat dihitung berdasarkan nilai absorbansi yang dihasilkan oleh spektrofotometer. Prinsip analisis kadar sulfat menggunakan spektrofotometri adalah sampel air direaksikan dengan larutan buffer A yang bersifat asam agar sulfat 
dapat larut dalam mineral, kemudian ditambahkan $\mathrm{BaCl}_{2}$ menjadikan suspensi $\mathrm{BaSO}_{4}$, adanya anion sulfat ditandai dengan terbentuknya endapan putih. Kemudian dibaca pada panjang gelombang maksimum $420 \mathrm{~nm}$ [7]. Dalam review artikel ini, dikaji mengenai metode spektrofotometri dalam pengukuran kadar sulfat dan aplikasi metode spektrofotometri untuk pengukuran kadar sulfat yang terdapat dalam beberapa jenis sampel air.

\section{METODE PENELITIAN}

Sumber data sekunder yang digunakan sebagai referensi diperoleh dari internet yang berupa artikel penelitian yang dipublikasikan di jurnal ilmiah nasional. Pencarian yang dilakukan untuk memperoleh referensi jurnal ilmiah menggunakan kata kunci: spektrofotometri, analisis kadar sulfat dalam air, analisis kadar sulfat menggunakan metode spektrofotometri. Pencarian artikel penelitian dilakukan lewat google chrome dengan beberapa situs search engine yaitu www.google.com dan https://scholar.google.com. Selanjutnya, artikelartikel yang telah diunduh lalu disimpan untuk dilakukan seleksi untuk dijadikan sebagai referensi dalam review artikel ini.

\section{HASIL DAN PEMBAHASAN}

Pada bagian ini, dijelaskan tentang metode spektrofotometri dalam pengukuran kadar sulfat dan aplikasi metode spektrofotometri untuk pengukuran kadar sulfat yang terdapat dalam beberapa jenis sampel air.

Tabel 1. Penentuan kadar sulfat menggunakan metode spektrofotometri dalam berbagai sampel air

\begin{tabular}{|c|c|c|c|c|c|c|}
\hline No & Sampel & Reagen & $\begin{array}{l}\text { Warna } \\
\text { larutan uji }\end{array}$ & $\begin{array}{l}\text { Panjang } \\
\text { gelombang } \\
(\mathbf{n m})\end{array}$ & Konsentrasi (mg/L) & Referensi \\
\hline 1. & $\begin{array}{c}\text { Air sumur bor } \\
\text { dan air filter }\end{array}$ & $\begin{array}{c}\text { Sulfaver } 4 \text { reagent } \\
\text { powder pillow }\end{array}$ & Putih keruh & 450 & 0,9602 & [3] \\
\hline 2. & $\begin{array}{l}\text { Air minum } \\
\text { dalam } \\
\text { kemasan }\end{array}$ & $\begin{array}{l}\mathrm{BaCl}_{2} \text {, larutan } \\
\text { buffer }\end{array}$ & - & 420 & $<0,0397$ & [4] \\
\hline 3. & $\begin{array}{l}\text { Air minum isi } \\
\text { ulang }\end{array}$ & - & - & 525 & $30-31$ & [8] \\
\hline 4. & Air bersih & $\begin{array}{l}\text { Buffer sulfat, } \\
\mathrm{BaCl}_{2}\end{array}$ & - & 420 & $3,623-12,834$ & [9] \\
\hline 5. & Air minum & Buffer A, $\mathrm{BaCl}_{2}$ & - & 420 & 10,368 & {$[10]$} \\
\hline 6. & Air hujan & $\begin{array}{l}\text { Asam sulfat, } \\
\text { larutan buffer, } \\
\mathrm{BaCl}_{2}\end{array}$ & - & 420 & $19,480-43,731$ & [11] \\
\hline 7. & $\begin{array}{c}\text { Air mineral } \\
\text { kemasan } \\
\text { gelas }\end{array}$ & $\begin{array}{l}\text { Larutan buffer, } \\
\mathrm{BaCl}_{2} \cdot 2 \mathrm{H}_{2} \mathrm{O}\end{array}$ & - & 420 & $2,0711-14,7011$ & [12] \\
\hline 8. & $\begin{array}{c}\text { Mata air } \\
\text { sumber }\end{array}$ & $\begin{array}{c}\text { Larutan buffer A, } \\
\mathrm{BaCl}_{2}\end{array}$ & - & 420 & 5,171 & [13] \\
\hline 9. & Air minum & $\begin{array}{c}\text { Sulfaver } 4 \text { sulfat } \\
\text { reagent }\end{array}$ & Putih keruh & 450 & $1,36-2,970$ & [14] \\
\hline 10. & $\begin{array}{c}\text { Air baku dan } \\
\text { air minum isi } \\
\text { ulang }\end{array}$ & $\mathrm{HCl} 2 \mathrm{M}, \mathrm{BaCl}_{2}$ & - & 400 & $2,67-4,76$ & [15] \\
\hline 11. & $\begin{array}{c}\text { Air minum } \\
\text { dalam } \\
\text { kemasan/AM } \\
\text { DK } \\
\text { (SNI 01- } \\
\text { 3554-2006) } \\
\end{array}$ & $\begin{array}{l}\text { Larutan buffer A, } \\
\qquad \mathrm{BaCl}_{2}\end{array}$ & - & 420 & - & [16] \\
\hline 12. & $\begin{array}{c}\text { Air dan air } \\
\text { limbah (SNI } \\
6989.20: 200)\end{array}$ & $\begin{array}{l}\text { Larutan buffer A, } \\
\qquad \mathrm{BaCl}_{2}\end{array}$ & - & 420 & - & [17] \\
\hline
\end{tabular}

Berdasarkan Tabel 1, dapat dilihat bahwa terdapat banyak perbedaan dalam hal reagen dan panjang gelombang. Artikel Nababan, 2018 dan
Madiah, 2017 mempunyai kesamaan pada reagen, panjang gelombang dan spektrofotometer yang digunakan. Artikel-artikel lainnya sama-sama 
menggunakan spektrofotometer UV-Vis tetapi terdapat perbedaaan dalam hal reagen dan panjang gelombang yang digunakan. Analisis sulfat menggunakan sulfaver 4 sulfat reagen apabila bereaksi dengar air yang menggandung sulfat akan berwarna putih keruh [14], sedangkan analisis sulfat menggunakan reagen $\mathrm{BaCl}_{2}$ apabila bereaksi dengan air yang mengandung ion sulfat akan membentuk endapan berwarna putih [9].

Di Indonesia, yang menjadi rujukan dalam penentuan kadar sulfat seharusnya adalah metode SNI terbaru atau terupdate. SNI 06-6898.20-2004 telah dinyatakan sudah tidak berlaku dan telah diganti dengan SNI 6989.20:2009 untuk pengukuran kadar sulfat $\left(\mathrm{SO}_{4}\right)$ dalam sampel air dan air limbah. Di sisi lain, SNI 01-3554-2006 digunakan sebagai rujukan penentuan kadar sulfat $\left(\mathrm{SO}_{4}\right)$ air minum dalam kemasan. Ananda, 2019, Hadiarti, 2015 dan Setyawan, 2016 menunjukkan bahwa ketiga artikel tersebut menggunakan prosedur yang sesuai dengan SNI 01-3554-2006 dengan sampel yang sama yaitu air minum dalam kemasan. Untuk artikel lain metode yang digunakan tidak sesuai dengan metode berdasarkan SNI, dan tidak disebutkan sumber metode yang digunakan.

Prinsip dari metode SNI 01-3554-2006 adalah dalam suasana asam ion sulfat diendapkan dengan $\mathrm{BaCl}_{2}$ kemudian terbentuk kristal $\mathrm{BaSO}_{4}$. Suspensi $\mathrm{BaSO}_{4}$ tersebut diukur absorbansinya pada panjang gelombang $420 \mathrm{~nm}$ dengan menggunakan spektrofotometer. Di sisi lain, prinsip dari metode SNI 6989.20:2009 yaitu dalam suasana asam, ion $\mathrm{SO}_{4}{ }^{2-}$ bereaksi dengan $\mathrm{BaCl}_{2}$ membentuk kristal $\mathrm{BaSO}_{4}$. Sinar yang diserap diukur menggunakan fotometer dari spektrofotometer. Selanjutnya, kadar sulfat ditentukan menggunakan perbandingan pembacaan absorbansi sampel dengan kurva kalibrasi.

Reagen yang digunakan pada metode SNI 013554-2006 dan metode SNI 6989.20:2009 sama yaitu larutan buffer A yang berisi campuran $30 \mathrm{~g}$ $\mathrm{MgCl}_{2} .6 \mathrm{H}_{2} \mathrm{O}, 5 \mathrm{~g} \mathrm{CH}_{3} \mathrm{COONa} .3 \mathrm{H}_{2} \mathrm{O}, 1 \mathrm{~g} \mathrm{KNO}_{3}, 2 \mathrm{~mL}$ $\mathrm{CH}_{3} \mathrm{COOH} 99 \%$ dilarutkan dalam air bebas mineral dan ditepatkan hingga $1 \mathrm{~L}$ kemudian ditambahkan 1 sendok takar reagen $\mathrm{BaCl}_{2}$ kemudian dibaca pada panjang gelombang yang digunakan $420 \mathrm{~nm}$. Perbedaan metode SNI 01-3554-2006 dan metode SNI 6989.20:2009 terletak pada rentang larutan standart, pada metode SNI 01-3554-2006 menggunakan rentang 0-40 mg/L dengan jarak $5 \mathrm{mg} / \mathrm{L}$ sedangkan pada metode SNI 6989.20:2009 menggunakan 1 blanko dan minimal 3 kadar deret larutan kerja dari larutan baku sulfat yang berbeda secara proposional yang berada pada rentang pengukuran. Identifikasi sulfat menggunakan metode spektrofotometri menurut metode SNI 01-3554-2006 dan metode SNI 6989.20:2009 sebagai berikut, sampel dipipet $100 \mathrm{~mL}$ kemudian dimasukkan kedalam erlenmayer dan ditambahkan larutan buffer
A $20 \mathrm{~mL}$, dihomogenkan dan ditambah 1 sendok takar $\mathrm{BaCl}_{2}$ kemudian dibaca pada panjang gelombang 420 $\mathrm{nm}$ menggunakan spektrofotometer. Larutan buffer A bersifat asam sehingga dapat melarutkan mineral. Terbentuknya endapan putih terjadi pada saat penambahan $\mathrm{BaCl}_{2}$ yang menunjukkan adanya reaksi ion sulfat yang diikat oleh ion $\mathrm{Ba}$ dan menjadi $\mathrm{BaSO}_{4}$ [9].

$$
\begin{aligned}
& \mathrm{SO}_{4}^{2-}+\mathrm{BaCl}_{2(\mathrm{aq})} \longrightarrow \mathrm{BaSO}_{4(\mathrm{~s})} \text { (endapan putih)+ } \\
& 2 \mathrm{Cl}^{-}(\mathrm{aq})
\end{aligned}
$$

Hasil analisis kadar sulfat dari berbagai sampel air, layak tidaknya digunakan untuk memenuhi kebutuhan sehari-hari harus dibandingkan dengan standar baku mutu yang telah diatur dalam Permenkes No. 492/MENKES/PER/IV/2010 tentang persyaratan kualitas air minum dan Permenkes No. 32 Tahun 2017 tentang persyaratan air untuk keperluan higiene sanitasi.

Didapatkan hasil kadar sulfat dari masingmasing sampel air berada di bawah ambang batas. Menurut Permenkes No. 492/MENKES/PER/IV/2010 tentang persyaratan kualitas air minum, kadar maksimum sulfat yaitu 250 mg/L sedangkan menurut Permenkes No. 32 Tahun 2017 tentang persyaratan air untuk keperluan higiene sanitasi, standar baku mutu (kadar maksimum) untuk kandungan sulfat dalam air dibatasi pada angka 400 $\mathrm{mg} / \mathrm{L}$. Dengan demikian, dapat disimpulkan bahwa sampel-sampel air yang telah diteliti layak untuk digunakan dalam kehidupan sehari-hari.

Sulfat dapat mempengaruhi perubahan rasa air menjadi rasa pahit dan dapat menimbulkan efek samping jika kadar sulfat dalam air memiliki konsentrasi yang tinggi. Bahaya ion sulfat apabila dikonsumsi dengan kandungan sulfat yang cukup besar dapat menyebabkan laxative/diare [3].

\section{KESIMPULAN}

Metode spektrofotometri dalam penentuan kadar sulfat dalam air dapat dilakukan menggunakan reagen $\mathrm{BaCl}_{2}$ yang diukur dengan spektrofotometer pada panjang gelombang $420 \mathrm{~nm}$. Penelitian Ananda, 2019, Hadiarti, 2015 dan Setyawan, 2016 dalam review artikel ini menggunakan prosedur yang sesuai dengan SNI 01-3554-2006 dengan sampel yang sama yaitu air minum dalam kemasan. Metode spektrofotometri dapat diaplikasikan untuk dalam penentuan konsentrasi ion sulfat dalam air sumur bor, air minum dalam kemasan, air minum isi ulang, dan air hujan. Menurut Permenkes No. 492/MENKES/PER/IV/2010 dan Permenkes No. 32 Tahun 2017, didapatkan hasil kadar sulfat dari masing-masing sampel air berada di bawah ambang batas. 


\section{DAFTAR PUSTAKA}

[1] Ngibad, K., \& Herawati, D. (2019). Analisis Kadar Klorida Dalam Air Sumur Dan PDAM Di Desa Ngelom Sidoarjo. JKPK (Jurnal Kimia Dan Pendidikan Kimia), 1-9.

[2] Permenkes, R. I. (2017). Standar Baku Mutu Kesehatan Lingkungan dan Persyaratan Kesehatan Air Untuk Keperluan Higiene Sanitasi, Kolam Renang, Solus per Aqua, dan Pemandian Umum.

[3] Nababan, G. R. J. (2018). Penentuan Kadar Sulfat dalam Air Sumur Bor dan Air Filter Medan Permai dengan Menggunakan Alat Spektrofotometer Portable Dr-2010.

[4] Ananda, M. S. (2019). Uji Kadar Sulfat Pada Air Minum Dalam Kemasan (AMDK) Secara Spektrofotometri UV-Vis. AMINA: Ar-Raniry Chemistry Journal, 1(1), 35-38.

[5] Ngibad, K. (2019). Penentuan Konsentrasi Ammonium dalam Air Sungai Pelayaran Ngelom. Medicra (Journal of Medical Laboratory Science/Technology), 2(1), 37-42.

[6] Ngibad, K. (2019). Penentuan Konsentrasi Ammonium dalam Air Sungai Pelayaran Ngelom. Medicra (Journal of Medical Laboratory Science/Technology), 2(1), 37-42.

[7] Ginting, C. B. (2019). Penentuan Kadar Sulfat $\left(\mathrm{SO}_{4}{ }^{2-}\right)$, Nitrat $\left(\mathrm{NO}_{3}{ }^{-}\right)$dan Fluorida $\left(\mathrm{F}^{-}\right)$dengan Menggunakan Spektrofotometer dalam Air Bersih di PT. Sucofindo Medan.

[8] Sinaga, F. N. (2016). Analisis Kadar Sulfat pada Air Minum Isi Ulang dengan Metode Spektrofotometri UV-Vis.

[9] Erviana, D., Budaya, A. W., Hariani, S., Winda, A., \& Sari, L. Y. (2018). Analisis Kualitatif Kandungan Sulfat dalam Aliran Air dan Air Danau di Kawasan Jakabaring Sport City Palembang. ALKIMIA: Jurnal Ilmu Kimia dan Terapan, 2(2), 1-4.

[10 Sitorus, R. R. I. (2017). Analisis Kadar Klorida $\left(\mathrm{Cl}^{-}\right)$, Sulfat $\left(\mathrm{SO}_{4}{ }^{2-}\right)$, dan Kekeruhan (Turbidity) pada Air Minum dari Vonten.

[11] Sutanto, S. (2013). Hujan Asam dan Perubahan Kadar Nitrat dan Sulfat dalam Air Sumur di Wilayah Industri Cibinong-citeureup Bogor. Jurnal Teknologi Pengelolaan Limbah, 14(1).

[12] Hadiarti, D. (2015). Penentuan Kadar Sulfat Air Mineral Kemasan Gelas Yang Beredar Di Pontianak Dengan Metode SM. Ed. 21 Th. 2005. SEMIRATA 2015.

[13] Setyawan, O. (2016). Analisis kandungan Fluorida, Sulfat dan Kelimpahan Fitoplankton pada Air Sumber Lanang Kabupaten Ngawi, Jawa Timur.

[14] Mudiah, L. (2017). Penetapan Kadar Sulfat dalam Air Di Salah Satu Perusahaan Air Minum Provinsi Sumatera Utara.
[15] Windri, R. E. (2011). Analisa Kandungan Cu (Ii) Dengan SSA Dan Ion Sulfat Dengan Spektrofotometer Sinar Tampak Pada Air Baku Dan Air Minum Isi Ulang Di Kota Pekanbaru (Doctoral dissertation, Universitas Islam Negeri Sultan Syarif Kasim Riau).

[16] Indonesia, S. N. (2006). Air minum dalam kemasan, Jakarta: Badan Stand. Nas..

[17] Indonesia, S. N. (2009). Air dan Air Limbah Bagian 72: Cara Uji Kebutuhan Oksigen Biokimia (Biochemical Oxygen Demand/BOD). SNI, 6989, 2009. 